\title{
Selected behaviors and health awareness of athletes practicing martial arts
}

\author{
Maria Alicja Nowak', Danuta Umiastowska ${ }^{2}$, Leonard Nowak ${ }^{3}$ \\ ${ }^{1}$ Department of Physical Education and Sport, Faculty of Physical Culture in Gorzów Wlkp. of the University School of Physical \\ Education in Poznan \\ ${ }^{2}$ Department of Methodology of Physical Education, Faculty of Physical Culture and Health Promotion, University of Szczecin \\ ${ }^{3}$ Department of Humanistic Foundations of Physical Culture and Tourism, Faculty of Physical Culture in Gorzów Wlkp. \\ of the University School of Physical Education in Poznan
}

Key words: athletes, smoking, alcohol consumption, risk factors

\section{Summary}

Introduction. The aim of the research was to find the answers to the questions of: which health-related behaviors are displayed by martial arts athletes, especially by champions, and what relationships there are between their health-related behaviors and their perception of health-threatening factors.

Material and methods. The study (between 2009 and 2011) involved 134 athletes practicing martial arts. The diagnostic survey method was employed, with the use of the questionnaire technique. In the statistical examination of the results the trait frequency, the $x^{2}$ independence test, and the multiple correspondence analysis were employed.

Results. Most athletes did not smoke (83.6\%). The athletes practicing taekwondo declared consumption of alcoholic beverages $(85.7 \%)$, while those practicing wrestling were most often non-drinkers $(87.0 \%)(p=0.0000)$. Athletes with the highest sporting level (champions) mostly did not smoke (93.3\%) and abstained from drinking alcoholic beverages (59.1\%). It was observed that those who regularly smoked more often failed to perceive tobacco consumption as a health risk $(92.3 \%)(p=0.0000)$. Athletes who frequently drank alcoholic beverages did not see this behavior as dangerous to their health $(41.7 \%)(p=0.0000)$.

Conclusions. Athletes who display health-oriented behaviors are highly aware of smoking and frequent consumption of alcoholic beverages being health-threatening factors. In reducing the risk factors related to smoking and frequent consumption of alcoholic beverages, martial arts-based on a specific philosophy and lifestyle that requires a reflective attitude towards one's own conduct and respecting the rules of fair play-should become a means of developing health-oriented behaviors among youth.

\section{Introduction}

Practicing qualified sport is not only connected with observing sporting rules, but also with the choice of a healthy lifestyle which is conducive to achieving high athletic performance. Choices concerning lifestyle are of great importance, especially in relation to martial arts [1]. Today, many varieties of martial arts are practiced, which attract and fascinate with their mystery, oriental origin, and specific rules, being propagated worldwide e.g. in motion pictures [2,3]. Practicing martial arts is connected not only with a high fitness level, but also with the values of the philosophy of budo, the choice of certain patterns of behavior and the path leading to the achievement of the pursued objectives $[4,5,6]$. These factors - conducive to the multilateral and comprehensive development of one's personality - make martial arts different from many other sports, despite similar principles of sports rivalry $[4,7]$. Studying behaviors and health awareness is also significant in search of models of athletes which could be shown to young people as worthy of imitation $[4,6,8]$.
Epidemiological studies have shown negative effects of smoking and multiplied risk of developing neoplastic diseases in smokers [9]. According to the Global Adult Tobacco Survey, conducted in 2009-2010 in Poland, $33.5 \%$ of adult men and $21.0 \%$ of adult women smoke daily (27.0\% of Poles in total) [10]. Ex-smokers represent $16.3 \%$ of the population. $14.0 \%$ of high school students admit smoking: $22.0 \%$ of boys and $10.0 \%$ of girls [11].

Consumption of alcoholic beverages, especially by sportspeople, increases susceptibility to injury and incidence of painful muscle spasms, reduces tolerance to effort, slows reaction time and decreases the safety of physical exertion [12]. In light of European health questionnaire survey conducted in 2009 (25.0\% of respondents reported abstinence, while alcohol use was declared by $85.0 \%$ of men and $65.0 \%$ of women [13]. One in five men and one in 22 drinking women admit drinking alcohol more frequently than once a week. Conservative estimates indicate that high-alcohol beverages are being replaced by low-alcohol ones. 
Conscious choice and individual responsibility for one's own health is extremely important for athletes' lifestyles, especially for those practicing martial arts, combining the physical with the spiritual improvement. The aim of the research, initiated in 2009 [14] is to find the answers to the questions of: which health-related behaviors are displayed by martial arts athletes, especially by champions, and what relationships there are between their health-related behaviors and their perception of health-threatening factors.

The following hypotheses were assumed:

1. Athletes with a high sporting level (martial arts champions) often exhibit behaviors conducive to health and the achievement of high athletic performance.

2. Perceiving smoking and consumption of alcoholic beverages as health-threatening factors affects athletes' choice of health-oriented behaviors.

\section{Material and methods}

The study was conducted between 2009 and 2011 and embraced 134 martial arts athletes, including 96 men and 38 women. The subjects practiced karate $(23$ people from the Karate Club "Samurai" - Szczecin), taekwondo (14 people from the Sports Club "Tornado" - Szczecin), wrestling (23 people from the Country Sports Club "Fenix" from Stargard Szczecinski) and amateur sumo (74 participants of the Poland Championships in Swidwin and Warsaw and the Poland Cup in Gorzow Wielkopolski). The majority of the respondents were athletes under 18 years of age $(56.7 \%)$, most often practicing wrestling. Taekwondo athletes were among the oldest. The respondents were mostly city dwellers (82.8\%). There was a small number of inhabitants of rural areas. The subjects were characterized by a secondary education or lower ( $87.3 \%$ were school or university students). $12.7 \%$ of the respondents had a higher education.

Athletes with a high sporting level represented $33.6 \%$ of the respondents (World, European and Poland Champions, and those with medal positions). Most championship titles in the study groups had sumo and karate athletes: (52.7\% and
$21.7 \%$ respectively). Over $2 / 3$ were individuals who had no achievements at this level. There were three distinct training period groups identified: below 4 years $(38.8 \%)$, between 4 and 10 years $(43.3 \%)$, and above 10 years $(17.9 \%)$. About $1 / 4$ of the subjects practiced martial arts daily, $56 \%$ trained between 3 and 4 times a week, and the remaining 19\% - 1 or 2 times a week.

In the study the diagnostic survey method was applied with a questionnaire on health-oriented lifestyle of athletes practicing martial arts $[14,15]$. In the statistical analysis of the results the trait frequency and the $X^{2}$ independence test were used. In order to show selected relations in a graphic and combined manner, after application of the $X^{2}$ statistics and ascertaining trait independence, the multiple correspondence analysis was employed. The variables in all their categories were presented on the plane. Comparison of the data from the figure with those from the table containing coordinates of two dimensions, combined with the $X^{2}$ independence test, enables reaching more general conclusions about the interrelations of all the variables and their categories [16].

\section{Results}

Most athletes did not smoke (83.6\%) (Table 1). Those who practiced taekwondo stopped smoking more often but the differences were statistically insignificant. Among those who had ever smoked there were $18.4 \%$ of the women and $15.6 \%$ of the men. Women less often gave up the habit $(5.3 \%$ and $7.3 \%$ respectively), but the differences were not significant. $85.7 \%$ of the athletes practicing taekwondo declared consumption of alcoholic beverages $\left(p=0.0000\right.$ for the $c^{2}$ test); frequent consumption was reported by almost $64.3 \%$ of them (1-2 times a week or more often) ( $p=0.0000$ for the $c^{2}$ test). Those who practiced wrestling, on the other hand, were most often non-drinkers (87.0\%).

Athletes with the highest sporting level (champions) mostly displayed more beneficial health-related behaviors: they did not smoke (93.3\%) $(p=0.0435)$ and abstained from drinking alcoholic beverages (59.1\%) (Table 2). Subjects with no cham-

Table 1. Smoking cigarettes and consumption of alcoholic beverages by athletes practicing martial arts ( $\chi 2$ independence test)

\begin{tabular}{|c|c|c|c|c|c|c|c|}
\hline \multirow{2}{*}{ Health-related behaviors } & \multicolumn{4}{|c|}{ Martial arts } & \multicolumn{2}{|c|}{ Total } & \multirow[b]{2}{*}{$\begin{array}{c}p \text { for } \\
\chi^{2} \text { test }\end{array}$} \\
\hline & $\begin{array}{c}\text { Amateur } \\
\text { Sumo }\end{array}$ & Karate & Wrestling & Taekwondo & $n=134$ & $\%$ & \\
\hline $\begin{array}{l}\text { Smoking cigarettes } \\
\text { Non-smokers } \\
\text { Regular smokers } \\
\text { Ex-smokers }\end{array}$ & $\begin{array}{l}85.1 \\
9.5 \\
5.4\end{array}$ & $\begin{array}{c}87.0 \\
13.0 \\
-\end{array}$ & $\begin{array}{l}82.6 \\
8.7 \\
8.7\end{array}$ & $\begin{array}{c}71.4 \\
7.2 \\
21.4\end{array}$ & $\begin{array}{c}112 \\
13 \\
9\end{array}$ & $\begin{array}{l}83.6 \\
9.7 \\
6.7\end{array}$ & $\begin{array}{l}\text { statistically } \\
\text { insignificant }\end{array}$ \\
\hline $\begin{array}{l}\text { Consumption of alcoholic beverage } \\
\text { No } \\
\text { Yes }\end{array}$ & $\begin{array}{l}45.2 \\
54.8\end{array}$ & $\begin{array}{l}43.4 \\
56.5 \\
\end{array}$ & $\begin{array}{l}87.0 \\
13.0 \\
\end{array}$ & $\begin{array}{l}14.3 \\
85.7 \\
\end{array}$ & $\begin{array}{l}65 \\
68 \\
\end{array}$ & $\begin{array}{l}48.9 \\
51.1 \\
\end{array}$ & 0.0000 \\
\hline $\begin{array}{l}\text { Frequency of alcoholic beverages } \\
\text { consumption } \\
\text { Non-drinkers } \\
\text { Rarely }^{*} \\
\text { Often }^{* *}\end{array}$ & $\begin{array}{l}45.1 \\
32.4 \\
22.5\end{array}$ & $\begin{array}{l}50.0 \\
36.7 \\
13.3\end{array}$ & $\begin{array}{l}87.0 \\
8.7 \\
4.3\end{array}$ & $\begin{array}{l}14.3 \\
21.4 \\
64.3\end{array}$ & $\begin{array}{l}65 \\
36 \\
29\end{array}$ & $\begin{array}{l}50.0 \\
27.7 \\
22.3\end{array}$ & 0.0000 \\
\hline
\end{tabular}

\footnotetext{
*- consuming alcoholic beverages 1-2 times a month or more rarely;
}

** - consuming alcoholic beverages 1-2 times a week or more often. 
Nowak M.A. et al., Behaviors and health awareness of athletes

Table 2. Smoking cigarettes and consumption of alcoholic beverages in relation to athletic achievements $(\chi 2$ independence test)

\begin{tabular}{|c|c|c|c|c|c|}
\hline \multirow[t]{2}{*}{ Health-related behaviors } & \multicolumn{2}{|c|}{ Athletic achievements } & \multicolumn{2}{|c|}{ Total } & $p$ for \\
\hline & Champions & Others & $n$ & $\%$ & $\chi^{2}$ test \\
\hline $\begin{array}{l}\text { Smoking cigarettes } \\
\text { Non-smokers } \\
\text { Smokers } \\
\text { Ex-smokers }\end{array}$ & $\begin{array}{l}93.3 \\
2.2 \\
4.5\end{array}$ & $\begin{array}{l}78.7 \\
13.5 \\
7.9\end{array}$ & $\begin{array}{c}112 \\
13 \\
9\end{array}$ & $\begin{array}{c}83.6 \\
9.7 \\
6.7\end{array}$ & 0.0435 \\
\hline $\begin{array}{l}\text { Consumption of alcoholic beverages } \\
\text { Non-drinkers } \\
\text { Drinking rarely } \\
\text { Drinking often }\end{array}$ & $\begin{array}{l}59.1 \\
25.0 \\
15.9\end{array}$ & $\begin{array}{l}45.4 \\
29.1 \\
25.6\end{array}$ & $\begin{array}{l}65 \\
36 \\
29\end{array}$ & $\begin{array}{l}50.0 \\
27.7 \\
22.3\end{array}$ & $\begin{array}{l}\text { statistically } \\
\text { insignificant }\end{array}$ \\
\hline
\end{tabular}

Table 3. Smoking cigarettes and consumption of alcoholic beverages in relation to martial arts athletes' perception of threats to their own health $(\chi 2$ independence test)

\begin{tabular}{|c|c|c|c|c|c|}
\hline \multirow[b]{2}{*}{ Health-related behaviors } & \multicolumn{2}{|c|}{ Perception of health threats } & \multicolumn{2}{|c|}{ Total } & \multirow{2}{*}{$\begin{array}{c}p \text { for } \\
\chi^{2} \text { test }\end{array}$} \\
\hline & Yes & No & $\mathrm{n}$ & $\%$ & \\
\hline $\begin{array}{l}\text { Smoking cigarettes } \\
\text { Non-smokers } \\
\text { Regular smokers } \\
\text { Ex-smokers }\end{array}$ & $\begin{array}{l}27.6 \\
51.7 \\
20.7\end{array}$ & $\begin{array}{c}2.6 \\
92.3 \\
5.1 \\
\end{array}$ & $\begin{array}{c}51 \\
9 \\
8 \\
\end{array}$ & $\begin{array}{c}75 \\
13.2 \\
11.8 \\
\end{array}$ & 0.0004 \\
\hline $\begin{array}{l}\text { Frequency of alcoholic beverages consumption } \\
\text { Non-drinkers } \\
\text { Rarely } \\
\text { Often }\end{array}$ & $\begin{array}{l}75.8 \\
18.2 \\
6.0\end{array}$ & $\begin{array}{l}27.1 \\
31.3 \\
41.7\end{array}$ & $\begin{array}{l}38 \\
21 \\
22\end{array}$ & $\begin{array}{l}46.9 \\
25.9 \\
27.2\end{array}$ & 0.0000 \\
\hline
\end{tabular}

Table 4. Data for Figure 1 along with explanations

\begin{tabular}{|c|c|c|c|c|c|c|c|}
\hline \multicolumn{8}{|c|}{ Arrangement of column and row coordinates for $n=80$} \\
\hline Symbol & Explanation & Dimension 1 & Dimension 2 & Symbol & Explanation & Dimension 1 & Dimension 2 \\
\hline Wrestling & Wrestling & -1.971 & -1.143 & 3 & Non-smokers & -0.296 & -1.652 \\
\hline $4 a$ & $\begin{array}{l}\text { Perceiving alcohol } \\
\text { consumption as a } \\
\text { health threat }\end{array}$ & -1.173 & -0.498 & Wrestling & Wrestling & -1.971 & -1.143 \\
\hline $2 a$ & $\begin{array}{l}\text { Perceiving smoking } \\
\text { cigarettes as a } \\
\text { health threat }\end{array}$ & -0.919 & -0.751 & Taekwon-do & Taekwondo & 1.072 & -0.802 \\
\hline $3 a$ & Non-drinkers & -0.812 & 0.627 & $2 a$ & $\begin{array}{l}\text { Perceiving smoking } \\
\text { cigarettes as a } \\
\text { health threat }\end{array}$ & -0.919 & -0.751 \\
\hline$A$ & Champions & -0.756 & 0.897 & $1 \mathrm{c}$ & Ex-smokers & -0.175 & -0.647 \\
\hline Sumo & Amateur sumo & -0.338 & 0.227 & $4 a$ & $\begin{array}{l}\text { Perceiving alcohol } \\
\text { consumption as a } \\
\text { health threat }\end{array}$ & -1.173 & -0.498 \\
\hline $1 b$ & Non-smokers & -0.296 & -1.652 & B & Other athletes & 0.378 & -0.449 \\
\hline $1 \mathrm{c}$ & Ex-smokers & -0.175 & -0.647 & $3 c$ & Drinking often & 0.770 & -0.399 \\
\hline $1 \mathrm{a}$ & Smokers & 0.061 & 0.308 & $3 b$ & Drinking rarely & 0.201 & -0.330 \\
\hline $3 b$ & Drinking rarely & 0.201 & -0.330 & Karate & Karate & 0.568 & 0.091 \\
\hline B & Other athletes & 0.378 & -0.449 & $4 b$ & $\begin{array}{l}\text { Not perceiving } \\
\text { alcohol consumption } \\
\text { as a health threat }\end{array}$ & 0.503 & 0.213 \\
\hline $4 \mathrm{~b}$ & $\begin{array}{l}\text { Not perceiving } \\
\text { alcohol consumption } \\
\text { as a health threat }\end{array}$ & 0.503 & 0.213 & Sumo & Amateur sumo & -0.338 & 0.227 \\
\hline $2 b$ & \begin{tabular}{|l|} 
Not perceiving \\
smoking cigarettes \\
as a health threat \\
\end{tabular} & 0.532 & 0.435 & $1 a$ & Smokers & 0.061 & 0.308 \\
\hline Karate & Karate & 0.568 & 0.091 & $2 b$ & $\begin{array}{l}\text { Not perceiving } \\
\text { smoking cigarettes } \\
\text { as a health threat }\end{array}$ & 0.532 & 0.435 \\
\hline $3 c$ & Drinking often & 0.770 & -0.399 & $3 a$ & Non-drinkers & -0.812 & 0.627 \\
\hline $\begin{array}{l}\text { Taekwon- } \\
\text { do }\end{array}$ & Taekwondo & 1.072 & -0.802 & A & Champions & -0.756 & 0.897 \\
\hline
\end{tabular}




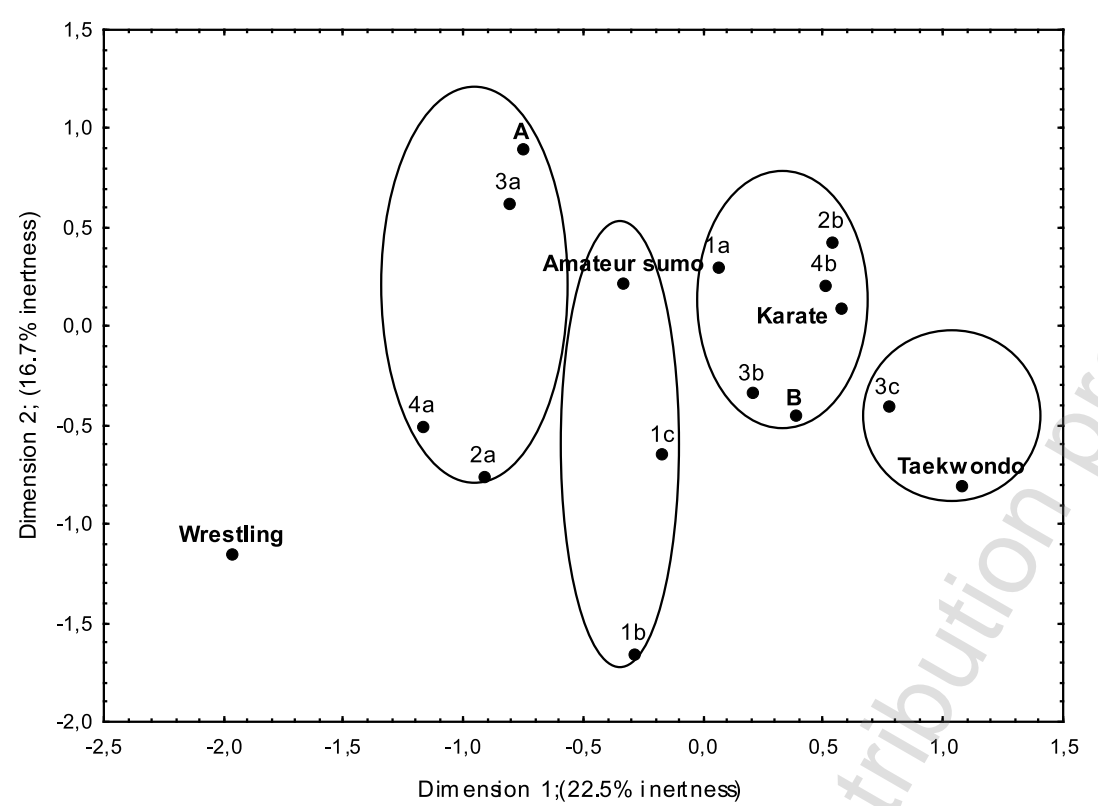

Fig. 1. Relationships between health-related behaviors and risk factors and the sporting level and type of martial arts practiced. See Table 4 for the data for the figure along with explanations of symbols

pionship titles more often declared smoking (13.5\%) and frequent consumption of alcoholic beverages $(25.6 \%)$.

It was observed that those who regularly smoked more often failed to perceive tobacco consumption as a health risk $(92.3 \%)$ ( $p=0.0000$ for $\mathrm{c}^{2}$ test) (Table 3). A similar situation occurred in relation to alcohol consumption. Athletes who frequently drank alcoholic beverages did not see this behavior as dangerous to their health $(41.7 \%)\left(p=0.0000\right.$ for $c^{2}$ test).

Relationships between health-related behaviors and perception of health risks and the sporting level and type of martial arts practiced by the respondents are shown in Fig. 1. The data for the figure along with explanations of symbols are provided in Table 4.

It was found that:

1. Athletes with the highest sporting level (medalists) (A) were more often non-drinkers ( $3 a$ ) and saw the consumption of alcoholic beverages and smoking as threats to their health: (2a and $4 a$ respectively);

2. Amateur sumo wrestlers were mostly non-smoking athletes (1b) and ex-smokers, who had used to smoke every day but had quit (1c);

3. Martial arts athletes with no championship titles (B) and karate athletes were characterized by smoking cigarettes (1a), not considering smoking a threat to their health (2b), infrequent consumption of alcoholic beverages (1-2 times a month or more rarely) (3b);

4. Taekwondo athletes were among those who consumed alcoholic beverages frequently (1-2 times a week of more often);

5. Athletes who practiced wrestling were in peripheral position, far from any of the groups analyzed.

\section{Discussion}

In pursuit of high athletic performance one of the necessary conditions to be met by athletes is the avoidance of behaviors which reduce their physical fitness and efficiency [17]. Complying with sporting rules also involves constant choices of values and behaviors in everyday life, i.e. choosing a particular lifestyle $[4,6,18]$. The hypothesis that athletes who achieve a high level of sporting excellence smoke cigarettes more rarely and avoid drinking alcoholic beverages was confirmed, but this group is not totally free from addictions either [19].

Smoking does not occur so commonly among martial artists as in Polish youth population. It concerned $16.4 \%$ of the athletes (aged 15 to 33), including ex-smokers who accounted for $6.7 \%$. Studies on Polish youth showed that the proportion of young daily smokers was higher and increased steadily from $16 \%$ at age 15 to about $25.0 \%$ among eighteenyear-olds [20]. According to the results of the GATS smoking affected $23.4 \%$ of men and $12.1 \%$ of women aged $15-19$, and $36 \%$ of men and $27.2 \%$ of women aged $20-29$ [10].

Negative relationships between smoking and sporting activities have been shown in a study of a selected group of runners. The number of smokers decreased with the increasing number of training hours [21]. There were also fewer smokers among female students who had taken exercise several times in the previous two weeks [22]. Young people who engaged in physical activity, less often took up the smoking habit, proportionally to the intensity, frequency and duration of exercise [23]. Research into health-related behaviors of 707 athletes practicing eastern martial arts found that tobacco was smoked by $15.9 \%$ of the population [24]. Unfortunately, 
the authors of the study did not analyze how many of the athletes had given up smoking.

Female martial art athletes were found to take up smoking slightly more often than men, and they were less likely to give up the habit. This behavior, justified by girls' conviction that smoking is conducive to weight reduction, had been observed in previous research $[25,26]$. Such beliefs were also expressed in the interviews by the respondents, especially those practicing amateur sumo.

Physical activity is also associated with other health-oriented behaviors (in addition to avoiding smoking - abstinence from alcohol or consumption of alcoholic beverages in moderate amounts and frequency) [27, 28, 29].

In the present study, $50 \%$ of athletes practicing martial arts reported abstinence, compared to $25.0 \%$ of the Polish population [13]. In light of some research findings, physical activity is associated with moderate consumption of alcoholic beverages [30], and it is believed that practicing sport at a competition level might help to avoid alcohol abuse [31]. According to other research, there is no apparent correlation in this regard. There was no significant reduction in consumption of alcoholic beverages among physically active people [32]. With increasing training experience, the number of subjects declaring consumption of alcoholic beverages among those who practiced martial arts grew [24]. It should be assumed that in this last case age had a greater impact on consumption of alcoholic beverages, as in relation to studied taekwondo athletes. In comparisons of alcoholic beverages consumption by 343 athletes and 400 students not practicing sport, in similar age categories, it was found that athletes drank less and more rarely [33].

On the other hand, the correlation between smoking and not perceiving this behavior as a threat to one's own health is high. A similar situation occurred regarding frequent consumption of alcoholic beverages (1-2 times a week or more often) and the perceived lack of health hazards. These results demonstrate the deficiency in health awareness among martial arts athletes. The hypothesis that the perception of risk factors as health-threatening or not health - threatening af- fects the choice of either health - oriented or anti - health behaviors was confirmed. Research findings confirm lower awareness of health threats involved in consumption of alcoholic beverages among sportspeople, compared with Physical Education students [33].

In all studies, researches underline difficulty in determining the prevalence of alcoholic beverages consumption. It was encountered in the present study as well. In the question about consumption of alcoholic beverages, the majority reported that they did not drink. However, a comparison of these answers with those to the next question, concerning frequency of alcohol consumption, revealed that subjects who considered themselves non-drinkers consumed alcohol 1-2 times a month or less frequently. In this situation, they were classified as rarely consuming alcoholic beverages. An analysis of prevalence of anti-health behaviors among martial arts athletes requires extraordinary inquisitiveness and caution in drawing conclusions.

\section{Conclusions}

1. Martial arts athletes with a high level of sporting excellence more often display health-oriented behaviors: they smoke cigarettes more rarely and avoid drinking alcoholic beverages.

2. Athletes who display health-oriented behaviors are highly aware of smoking and frequent consumption of alcoholic beverages being health-threatening factors. Anti-health behaviors are taken up by athletes with low health awareness.

3. In reducing the risk factors related to smoking and frequent consumption of alcoholic beverages, martial arts based on a specific philosophy and lifestyle that requires a reflective attitude towards one's own conduct and respecting the rules of fair play - should become a means of developing health-oriented behaviors. Patterns of behavior of chosen athletes who practice martial arts should be popularized among youth.

\section{References}

1. Piórko-Pawliński A. Why karate apart from the past has also future - pro-health function of martial arts in a broader context. Journal of Combat Sports and Martial Arts.2009; 1(2); Vol. 1, 53-57.

2. Cynarski WJ. Teoria i praktyka dalekowschodnich sztuk walki w perspektywie europejskiej. [In Polish] [Theory and practice of Far Eastern martial arts in a European perspective]. Rzeszów: Wydawnictwo Uniwersytetu Rzeszowskiego; 2004.

3. Obodyński K. Specyfika jūjutsu i jūdō. [In Polish] [The specific characters of Jujutsu and Judo]. Rocznik Naukowy Idō - Ruch dla Kultury, 2001; II: $46-51$

4. Cynarski WJ. Values of martial arts in the light of the anthropology of martial arts. Journal of Combat Sports and Martial Arts. 2012; 1(2); Vol. 3, 1-4. DOI: 10.5604/20815735.1047608

5. Kalina RM, Jagiełło W. (eds.). Wychowawcze i utylitarne aspekty sportów walki. [In Polish] [Educational and utilitarian aspects of combat sports].Warszawa: AWF; 2000.

6. Tokarski S. Judo contribution to martial arts - techniques, strategies, values. Journal of Combat Sports and Martial Arts. 2012; 2(2); Vol. 3, 141-145. DOI: 10.5604/20815735.1047662

7. Budnik D. Personality profile, stress coping styles and self-image of karate competitors with different attitudes towards meditation. Journal of Combat Sports and Martial Arts, 2010; 1(2); Vol. 1, 15-19.

8. Sikorski W, Błach W. Judo for health. Journal of Combat Sports and Martial Arts. 2010; 2(2); Vol. 1, 123-124.

9. Glover ED, Payne PN, Payne TJ. Treating nicotine dependence. Am J Med Sci. 2003; 326(4): 183 - 186. 
10. Globalny sondaż dotyczący używania tytoniu przez osoby dorosłe (GATS). [In Polish] [Global Adult Tobacco Survey (GATS)]. Polska 2002010. Ministerstwo Zdrowia, WHO, Regional Office for Europe.

11. Wojtyła-Buciora P, Marcinkowski JT, Wojtyła A. Palenie tytoniu przez licealistów - w opinii młodzieży i ich rodziców. [In Polish] [Tobacco smoking by high school students - in the opinion of young people and their parents]. Probl Hig Epidemiol, 2011; 92(2): 319 - 326.

12. Kołaciński Z. Alkohol jako zagrożenie dla osób aktywnych ruchowo. [In Polish] [Alcohol as a threat for physically active people]. In: A. Jegier A. (eds.). Dozwolone i niedozwolone wspomaganie zdolności wysiłkowych człowieka. [In Polish] [Permitted and prohibited support of human physical exercise capacity]. Łódź: PTMS; 2007: 188 - 209.

13. Europejskie Ankietowe Badanie Zdrowia w 2009 r. [In Polish] [European Health Interview Survey in 2009]. Wyniki badań GUS. www.stat. gov.pl (date of access 20.05.2013).

14. Nowak MA, Kitowska M, Rynkiewicz T, Kuriańska-Wołoszyn J, Żurek P, Rynkiewicz M. Health-oriented attitudes in amateur sumo wrestlers. Arch Budo 2009; 5: 165 - 69.

15. Nowak MA, Kitowska M, Rynkiewicz T, Piekarski R, Rynkiewicz M, Żurek P. Motives vs. age, training experiences, and sporting level in sumo wrestlers. Arch Budo 2010; 6(1): 7 - 12.

16. Van Buuren J, de Leeuw JV. Equality constraints in Multiple Correspondence Analysis. Multivar. Behav. Res. 1992; $27(4): 567$ - 583.

17. Rutkowska K. Training needs of judo practitioners regarding sport psychology. Journal of Combat Sports and Martial Arts. 2012; 2(2); Vol. 3, 97-101. DOI: $10.5604 / 20815735.1047655$

18. Nowak MA. Physical culture patterns in the lifestyle of the Polish society Pol. J. Sport Tourism 2013; 20: 3 - 12.

19. Sokołowski M, Kaiser A, Czerniak U, Tomczak M, Bręczewski G. Wrestlers' health - biological, behavioural and axiological aspects. Arch Budo 2012; 8(1): 37 - 43.

20. Oblacińska B, Woynarowska B. (eds.). Zdrowie subiektywne, zadowolenie z życia i zachowania zdrowotne uczniów szkół ponadgimnazjalnych w Polsce w kontekście czynników psychospołecznych i ekonomicznych. [In Polish] [Subjective health, life satisfaction and health behaviors of secondary school students in Poland in the context of psychosocial and economic factors]. Warszawa: Instytut Matki i Dziecka; 2006.

21. Wankel LM, Sefton JM. Physical activity and other lifestyles behaviours. In: Bouchard C, Shephard RJ, Stephens T. (eds.). Physical Activity, Fitness, and Health. Champaign, Human Kinetics Publishers; 1994: 530 - 550.

22. Steptoe A, Wardle J, Fuller R, Holte A, Justo J, Sandermann R. et al. Leisure - time physical exercise. Prevalence, attitudinal correlates, and behavioral correlates among young Europeans from 21 countries. Prev. Med. 1997; 26(6): 845 - 854.

23. Audrain-McGovern J, Rodriguez D, Moss HB. Smoking progression and physical activity. Cancer Epidemiol Biomark Prevention 2003; 12 : $1121-9$.

24. Myśliwiec L, Sygit M, Ciechanowicz B. Health behaviour in people practicing the Eastern martial arts. Zdr Publ. 2004; $114(3)$ : 371 - 376.

25. Saarni SE, Silventoinen K, Rissanen A, Sarlio-Lähteenkorva S, Kaprio J. Inentional weight loss and smoking in young adults. Int J Obesity 2004; 28: 796 - 802.

26. Stice E, Martinez E, Martinez BA. Cigarette smoking prospectively predicts retarded physical growth among female adolescents. Journal of Adolscent Health 2005; 37: 363 - 370. DOI:10.1016/j.jadohealth. 2004.10.017.

27. Mensink GBM, Losse N, Oomen CM. Physical activity and its association with other lifestyle factors. Eur J Epiedmiol. 1997; $13(7): 771$ - 778.

28. Aarnio M, Winter T, Kujala U, Kaprio J. Association of health related behavior, social relationships, and health status with persistent physical activity and inactivity; a study of Finnish adolescents twins. Br J Sports Med. 2002; 36(5): 360 - 364. DOI:10.1136/bjsm.36.5.360.

29. Jakicic JM, Wing RR, Winters-Hart C. Relationships of physical activity to eating behaviors and weigth loss in women. Med. Sci. Sports Exerc. 2002; 34(10): 1653 - 1659.

30. Smothers B, Bertolucci D. Alcohol consumption and health-promoting behaviour in a U.S. household sample: leisure-time physical activity. J Stud Alcohol. 2001; 62(4): 467 - 476.

31. Werch Ch, Moore M, DiClemente CC, Owen DM, Jobli E, Bledsoe R. A sport-based intervention for preventing alcohol use and promoting physical activity among adolescents. Journal of School Health 2003; 73: 380 - 388.

32. Westerterp KR, Meijer EP, Goris AHC, Kester AD. Alkohol energy intake and habitual physical activity in older adults. Br J Nutr. 2004; 13(1): 55-62. DOI: 10.1079/BJN20031013.

33. Wrona-Wolny W. Uwarunkowania i funkcje spożywania alkoholu przez sportowców. [In Polish] [Conditions and functions of alcohol consumption by athletes]. Kraków: AWF; 2007.

\section{Address for correspondence:}

Maria Alicja Nowak

ul. Skowronka 4, 66-415 Zdroisko, woj. lubuskie, Poland

e-mail: maria-nowak@wp.pl; telefon: 606219840

Received: 05.01.2013

Accepted: 13.04 .2013 